\title{
Electrical Resistivity Survey in Bukit Bunuh, Malaysia for Subsurface Structure of Meteorite Impact Study
}

\author{
Mark Jinmin $^{1 *}$, Rosli Saad ${ }^{1}$, Mokhtar Saidin ${ }^{2}$, Andy A. Bery ${ }^{1}$ \\ ${ }^{1}$ Geophysics Section, School of Physics, Universiti Sains Malaysia, Penang, Malaysia \\ ${ }^{2}$ Centre for Global Archaeological Research, Universiti Sains Malaysia, Penang, Malaysia \\ Email: markjinmin@yahoo.co.uk
}

Received 2013

\begin{abstract}
An electrical resistivity tomography (ERT) study was conducted at Bukit Bunuh, Lenggong Perak (Malaysia). The study is to justify the features and environmental subsurface geological structure which is due to the meteorite impact. The ERT survey used resistivity equipments comprises of 4 survey lines with $5 \mathrm{~m}$ electrode intervals, covering an area of approximately $64 \mathrm{~km}^{2}$. The survey lines were carried out using 'roll-along' technique. The data were processed and analysed using RES2DINV, Excel and Surfer software in order to produce electrical resistivity tomography for qualitative interpretations. The results show the variation of resistivity value and faults. The 2-D resistivity results generally show the study area was divided into two main zones, alluvium with resistivity value of $10-800 \Omega \mathrm{m}$, and bedrock with resistivity value of $>1500 \Omega \mathrm{m}$ and depth of $20-40 \mathrm{~m}$. There are lots of fractured zones which are different than normal, identified along the survey lines. The South-North line shows the fractured zones were identified at $760-3800 \mathrm{~m}$ and $4700-5900 \mathrm{~m}$. The West-East line, the fractured zone was identified at $1545-6570 \mathrm{~m}$ and North-West to South-East line, the fractured zone was identified at $740-5850 \mathrm{~m}$. Meanwhile, South-West to North-East line, the fractured zone was identified at $720-1520 \mathrm{~m}$. These interesting results were indicated at position of longitude; $100.965-100.978$ and latitude; $5.056-5.066$ where the bedrock depth is $40-60 \mathrm{~m} \mathrm{MSL}$ and highly fractured. The area was surrounded by high elevated bedrock. Integration of 2-D resistivity results with boreholes is successful give valid and reliable results. The results of the study indicate that these geophysical approaches have a capability of retrieving the meteorite impact subsurface of the studied area.
\end{abstract}

Keywords: Resistivity; Meteorite Impact; Interesting; Integration; Successful

\section{Introduction}

Geophysical survey in archaeological most often refers to the ground-based physical sensing methods used for archaeological mapping or imaging. Geophysical survey methods are neither invasive nor destructive methods using in environmental study. For this reason, it is often used where preservation is the goal, and to avoid disturbance. Geophysical survey results can be used to guide preservation and to give archaeologists insight into the patterning of non-excavated parts of the study site. Geophysical method used in this study was to create maps of the subsurface archaeological features. Features are the non-portable part of the archaeological record, whether standing structures or traces of human activities lest in the soil. In this paper, electrical resistivity was used to detect the buried features when their physical properties contrast measurable with the surroundings. Although geophysical survey has been used in the past with inter-

${ }^{*}$ Corresponding author. mittent success, good results are very likely when it is applied appropriately. It is most useful when it is used in a well-integrated research design where interpretation can be tested and refined.

Geophysical methods in archaeological has gained wide acceptance in the past decade within the general archaeological community. There are now practitioners on all contents and discipline can be found in the curriculums of many academic departments world-wide. Its root laid in natural sciences, where techniques were developed by scientists with geophysics, geology and physics ground [1-3]. The roots of archaeological geophysics lie in its ability as a prospection tool to locate, map and produce images of buried cultural materials [4].

\section{Geology Setting}

The survey covered approximately $64 \mathrm{~km}^{2}$ with mainly agricultural land (palm estate) at the centre of the area. Meanwhile toward the West and East of the survey area was primary jungle. Generally the survey area was un- 
dulating and some part was very rough since the survey lines running parallel and across Sungai Perak and two mountain ranges, Bintang Range and Titiwangsa Range. Bukit Bunuh is situated in Lenggong Valley area which is at the north part of Kota Tampan. Generally, Lenggong Valley consists of few unit lithologies, such as alluvium, tetra dust and granitic rock. The alluvium unit was situated along the river. The quaternary sedimentation was represented by alluvium unit and tetra dust. Granitic rock was represented by Late Jurassic-Lower Carboniferous which dominates the whole of Lenggong Valley which also originated from Bintang Range on the west Lenggong [5].

\section{Materials and Methods}

In this paper, the survey used electrical resistivity method to reach study goal. The purpose of resistivity survey is to determine the subsurface resistivity distribution by making measurement on the ground surface. Therefore, the true resistivity of the subsurface can be estimated. Electrical resistivity topography were obtained using the georesistivity meter SAS4000 (ABEM Instruments) connected to a multielectrodes system. Pole-dipole array was used with minimum electrodes spacing on the surface of $5.0 \mathrm{~m}$. The pole-dipole array has relatively very good horizontal coverage, but it has a significantly higher signal strength compared with dipole-dipole and it is not as sensitive to telluric noises as the pole-pole array. In order to obtained 2-D resistivity models, the data obtained were interpreted through the inversion algorithm, RES2DINV software [6]. The measured values of apparent resistivity provide, in fact, a first preliminary image of the electrical subsurface structure denominated as the "pseudosection". In a second step, the apparent resistivity measurements are transformed into true resistivity values using the rapid inversion algorithm [6].

\section{Results and Discussion}

The 2-D resistivity results obtained by the inversion algorithm performed with the RES2DINV software are shown below. Electrical resistivity values are related to geological parameters of the subsurface and, in particular, resistivity values are controlled by the types of rock and fluid. 2D resistivity results in Figures 1-3 generally shows the studied area was divided into two main zones, alluvium with resistivity value of $10-800 \Omega \mathrm{m}$, and bedrock with resistivity value of $>1500 \Omega \mathrm{m}$ and depth of 20 - $40 \mathrm{~m}$. There are lots of fractures zone which is different than normal identified along the studied survey lines. Line South-North, the fractured zones were identified at $760-3800 \mathrm{~m}$ and $4700-5900 \mathrm{~m}$. For the West-East line, the fractured zones were identified at $1545-6570 \mathrm{~m}$. North-West to South-East line, the fractured zone was identified at $740-5850 \mathrm{~m}$ and South-West to North-East line, the fractured zone was identified at $720-1520 \mathrm{~m}$. Figure 4 shows the bedrock topography map of resistivity surveys with respect to ground surface topography. The interesting results was indicated at position of longitude; 100.965 - 100.978 and latitude; 5.056 - 5.066 (Black rectangle) where the bedrock depth is $40-60 \mathrm{~m}$ from mean-sea-level (MSL) and highly fractured. The area was surrounded by high elevated bedrock. Table 1 shows one of the borehole data which located at the studied area that assists in data interpretation of geophysical method.

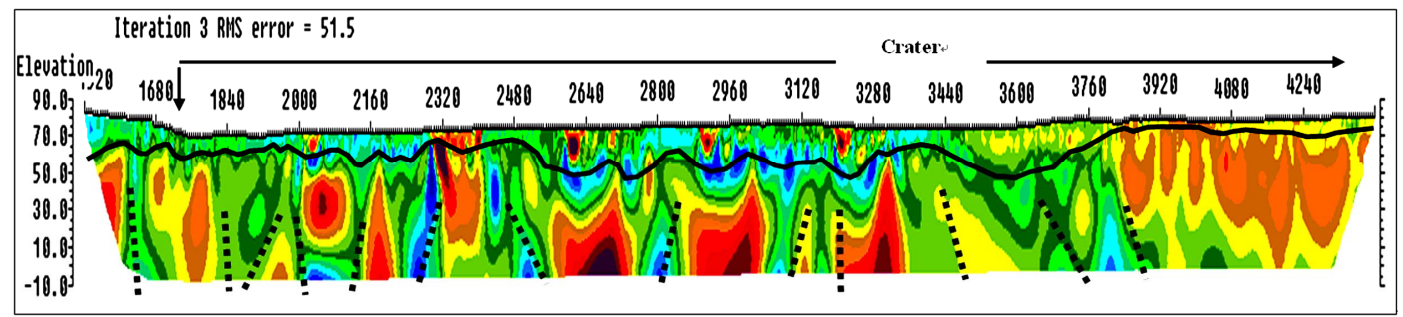

(a)

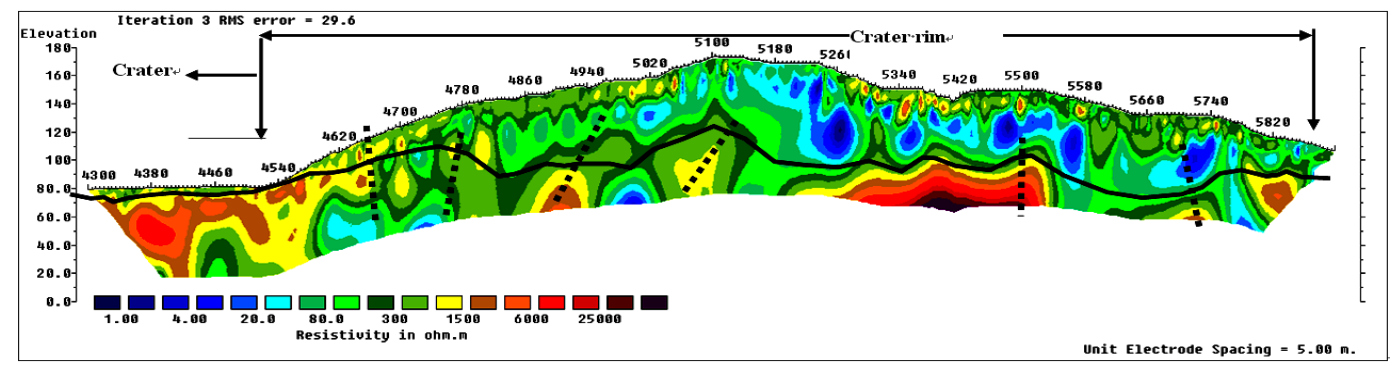

(b)

Figure 1. Resistivity section of South to North line, 8 km length. (a) Resistivity section 1520 - 4400 m; (b) Resistivity section 4300 - $6000 \mathrm{~m}$. 


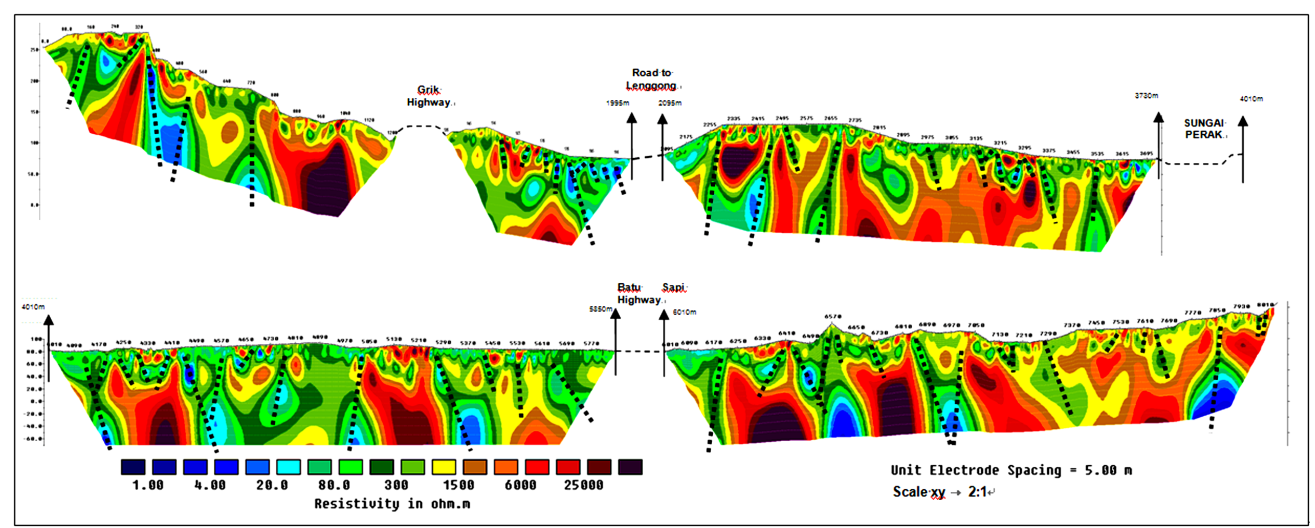

Figure 2. Resistivity section of West to East line, 0 - 8050 m.

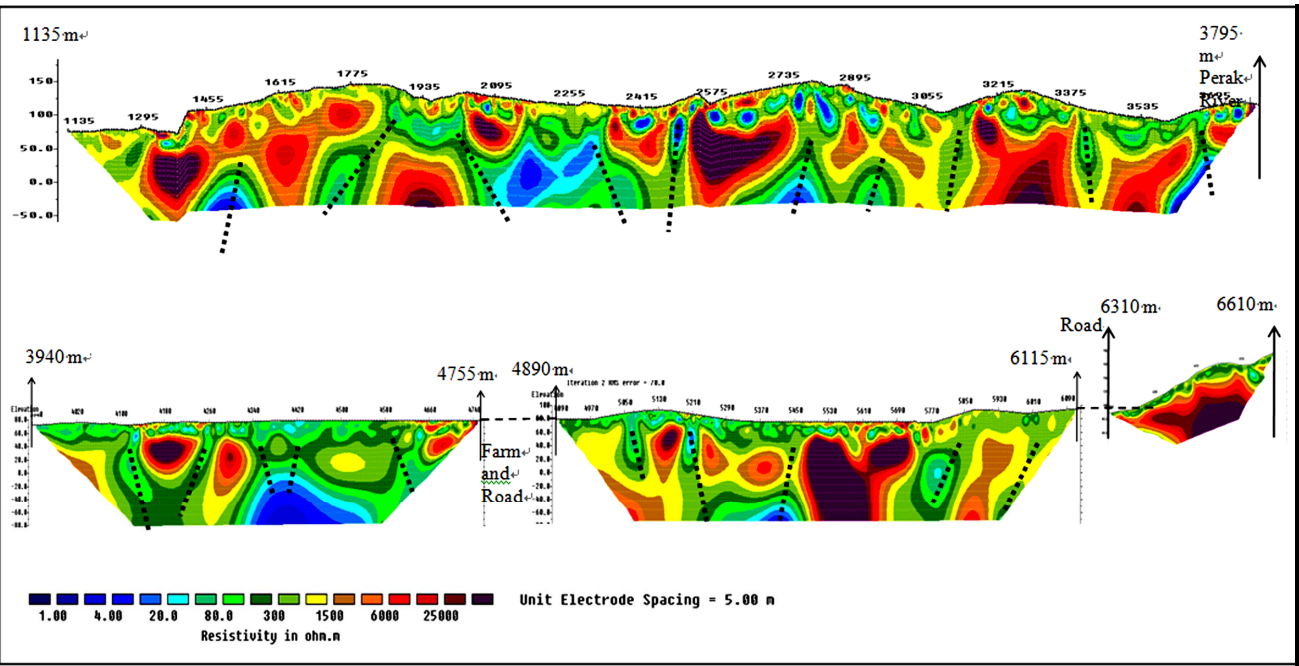

Figure 3. Resistivity section of North-West to South-East line, 1135 - 6610 m.

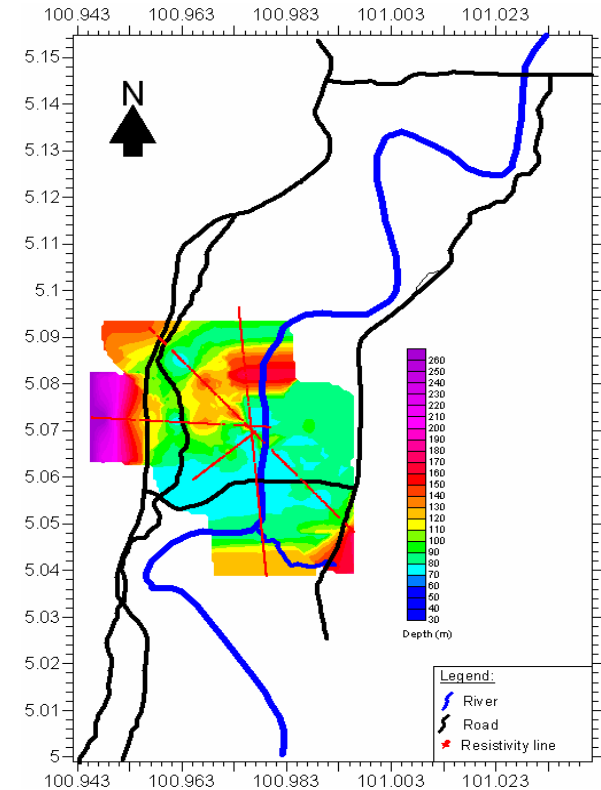

(a)

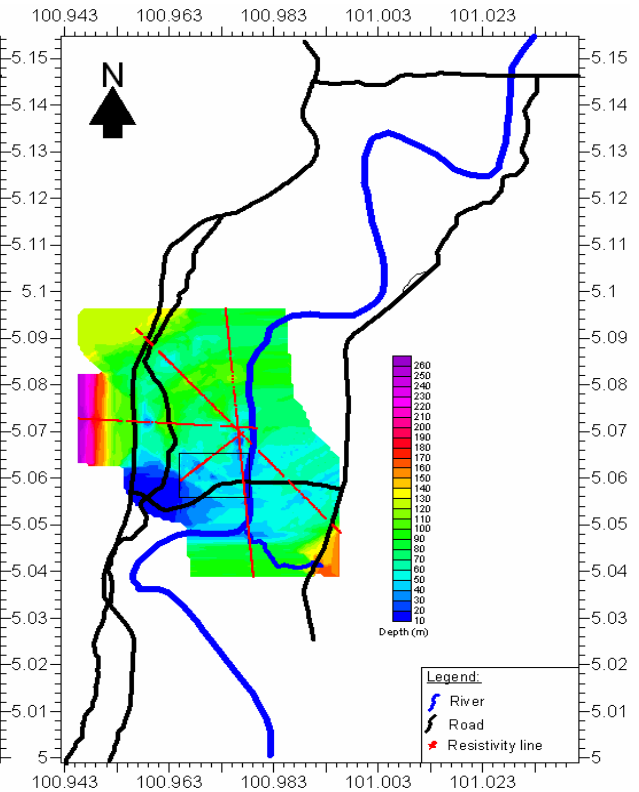

(b)

Figure 4. Resistivity topography map; (a) ground surface; (b) bedrock. 
Table 1. Borehole, BH 3 at Bukit Bunuh with lithology.

\begin{tabular}{c|c|c|c}
\hline $\begin{array}{c}\text { Sample } \\
\text { depth (m) }\end{array}$ & Lithology & $\begin{array}{c}\text { Colour } \\
\text { (Munsell chart) }\end{array}$ & Details \\
\hline 1.50 & Literite & $\begin{array}{c}\text { Yellowish brown and } \\
\text { light grey }\end{array}$ & $\begin{array}{c}\text { Weathered granite to literate. } \\
\text { Existing of pyrite and mica. }\end{array}$ \\
\hline 3.00 & Literite & $\begin{array}{c}\text { lighter grey, yellowish } \\
\text { brown and greenish grey }\end{array}$ & $\begin{array}{c}\text { Weathered granite to literate. } \\
\text { Exting of courser quartz and pyrite } \\
\text { and mica mineral. }\end{array}$ \\
\hline 4.00 & Weathered & & $\begin{array}{c}\text { Granite impact (Bedrock) } \\
\text { Granite }\end{array}$ \\
\hline 5.00 & Granite & & $\begin{array}{c}\text { Granite impact (Bedrock dominated } \\
\text { by quartz and feldspar) }\end{array}$ \\
\hline 7.10 & Granite & & Granite impact (Bedrock) \\
\hline & Granite & & Granite impact (Bedrock) \\
\hline
\end{tabular}

\section{Conclusions}

The 2-D resistivity survey method conducted at Bukit Bunuh, Malaysia can be used as a geological mapping tool to provide detail information on underground subsurface. The results presented in this paper successfully detect fractures at various depths and their position. The highly fractured bedrock was identified at longitude $100.965-100.978$ and latitude $5.056-5.066$. This could be one of the possible causes of the meteorite impact at this area.

\section{Acknowledgements}

The authors for this paper would like to thank Centre for Global Archaeological Research (CGAR) Universiti Sains Malaysia for assist in financial for this project. Lastly authors for this paper would like to thank Mr. Yaakub Othman and Mr. Mydin Jamal for assist in data acquisition during this project in Bukit Bunuh area.

\section{REFERENCES}

[1] J. W. Weymouth, "Geophysical Methods of ArchaeoLogical Site Survey," Advance in Archaeological Method and Theory, Vol. 9, 1986, pp. 370-382.

[2] I. Schollar, A. Tabbagh, A. Hesse and I. Herzog, "Archaeological Prospecting and Remote Sensin Topics in Remote Sensing," Cambridge University Press: Cambridge, Vol. 2, 1990.

[3] A. Aspinall, C. Gaffney and A. Schmidt, "Magnetometry for Archaeologists," Altamia Press: Lanham, 2008.

[4] L. B. Conyers, "Ground-Penetrating Radar for Anthropological Research,” Antiquity, Vol. 84, No. 323, 2004, pp. 175-184.

[5] M. Saidin, "Kajian Perbandingan Tapak Paleolitik Kampung Temelong dengan Kampung Kota Tampan dan sumbangannya terhadap kebudayaan zaman Pleistosein akhir di Asia Tenggara," Malaysia Museum Journal, Vol. 32, 1993

[6] M. H. Loke and R. D. Barker, "Rapid Least-Squares Inversion of Apparent Resistivity Pseudosections Using a Quasi-Newton Method," Geophysical Prospecting, Vol. 44, No. 1, 1996, pp. 131-152. doi:10.1111/j.1365-2478.1996.tb00142.x 